Anis Baraka MD, Samar Jabbour MD, Zafer Tabboush MD, Abla Sibai MS, Antoine Bijjani MD, Karam Karam MD

\title{
Onset of vecuronium neuromuscular block is more rapid in patients undergoing Caesarean section
}

This investigation was carried out in ten patients undergoing elective Caesarean section and the results were compared with those of a control group of ten nonpregnant females of the same age group. The study investigated the onset of vecuronium neuromuscular block and the conditions of tracheal intubation when ketamine $\left(1.5 \mathrm{mg} \cdot \mathrm{kg}^{-1}\right)$-vecuronium $\left.100 \mu \mathrm{g} \cdot \mathrm{kg}^{-1}\right)$ sequence was used for rapid-sequence induction of anaesthesia. The ulnar nerve was stimulated supra-maximally at the wrist with train-of-four stimuli every $20 \mathrm{sec}$, and the electromyographic response of the adductor pollicis muscle was displayed. The onset of 50\% neuromuscular block as monitored by electromyography was shorter in the Caesarean group ( $80 \pm 30 \mathrm{sec}$ ) than in the control group $(144 \pm 43 \mathrm{sec})$. The conditions of intubation at $50 \%$ block were adequate in both groups. Also, the onset of $90 \%$ block was shorter in the Caesarean group. The time of recovery to $T /$ control ratio of $25 \%$ was longer in the Caesarean group (46 $\pm 10 \mathrm{~min})$ than in the control patients (28 $\pm 10 \mathrm{~min}$ ). The results show that administration of vecuronium according to body weight results in a more rapid onset and delayed recovery of neuromuscular block in pregnant women undergoing Caesarean section than in the nonpregnant control patients.

\section{Key words}

ANAESTHESIA: obstetrical;

ANAESTHETIC TECHNIQUES: induction; NEUROMUSCULAR RELAXANTS: vecuronium.

From the Departments of Anesthesiology, Obstetrics \& Gynaecology, and Epidemiology and Biostatistics, American University of Beirut, Beirut, Lebanon.

Address correspondence to: Dr. Anis Baraka, Professor and Chairman, Department of Anesthesiology, American University of Beirut, Beirut, Lebanon.

Accepted for publication 16th September, 1991.
Cette étude fut conduite chez dix patientes devant subir une césarienne élective et les résultats furent comparés à un groupe contrôle de dix patientes non gravides ayant le même âge. Cette étude investigue l'installation du bloc neuromusculaire après vécuronium et les conditions d'intubation trachéale à la kétamine $\left(1,5 \mathrm{mg} \cdot \mathrm{kg}^{-1}\right)$-vécuronium $\left(100 \mu \mathrm{g} \cdot \mathrm{kg}^{-1}\right)$ qui ont été utilisés pour une induction rapide de l'anesthésie. Le nerf cubital fut stimulé de façon supramaximale au niveau du poignet avec l'ondée-de-quatre (train-of-four) chaque $20 \mathrm{sec}$, et la réponse électromyographique de l'adducteur du pouce enregistrée. L'installation de 50\% du bloc neuromusculaire, tel que démontré parélectromyographie, fut plus courte dans le groupe césarienne $(80 \pm 30 \mathrm{sec})$ que le groupe contrôle $(144 \pm 43 \mathrm{sec})$. Les conditions d'intubation à $50 \%$ de bloc furent adéquates dans les deux groupes. Aussi, l'installation d'un bloc à $90 \%$ était plus court dans le groupe césarienne. Le temps de récupération pour un rapport $T_{l} /$ contrôle de $25 \%$ était plus long pour le groupe césarienne ( $46 \pm 10 \mathrm{~min}$ ) que le groupe contrôle $(28 \pm 10 \mathrm{~min})$. Les résultats démontrent que l'administration de vécuronium selon le poids amène une installation du bloc neuromusculaire plus rapide et une récupération plus tardive chez les patients devant subir une césarienne que celles non gravides du groupe contrôle.

Vecuronium has been suggested for rapid-sequence induction of anaesthesia in patients undergoing Caesarean section. ${ }^{1}$ Also, ketamine has been used for induction of anaesthesia for Caesarean section. ${ }^{2}$ The present report investigated the onset of neuromuscular blockade and the conditions for tracheal intubation when a ketaminevecuronium sequence was used for rapid-sequence induction in patients scheduled for elective Caesarean section. The results were compared with that achieved when the same sequence was used in a control group of nonpregnant women.

\section{Methods}

The investigation was approved by the Institution Research Committee and informed consent was obtained. Ten full-term pateints undergoing elective Caesarean 
section were investigated; their mean age was $30 \pm 6 \mathrm{yr}$ and mean body weight $75 \pm 11 \mathrm{~kg}$. The control group of ten nonpregnant women were aged $28 \pm 8 \mathrm{yr}$ and weighed $58 \pm 9 \mathrm{~kg}$, who were scheduled for gynaecological procedures such as laparoscopy and tubal ligation.

All patients received premedication with atropine $0.6 \mathrm{mg} \mathrm{im}$. In the operating room, patients were monitored with ECG, non-invasive blood pressure measurement (Omega 1400), and pulse oximeter (Radiometer Copenhagen). An intravenous infusion of lactated Ringer's solution was started on the dorsum of the left hand, and neuromuscular transmission was monitored in the right hand.

\section{Neuromuscular monitoring}

Neuromuscular transmission was monitored with a Datex Relaxograph monitor. The ulnar nerve was stimulated supramaximally at the wrist every $20 \mathrm{sec}$, with train-offour stimuli at a frequency of $2 \mathrm{~Hz}$ and the electromyographic response of the adductor pollicis was displayed. Electromyographic monitoring started in the awake patient during the preoxygenation period, and was continued during induction of anaesthesia and throughout the surgical procedure.

When a steady electromyographic response was displayed, anaesthesia was induced using a rapid-sequence technique in both the Caesarean and control groups. Following preoxygenation by a face mask with five litres of $100 \%$ oxygen for three to five minutes, anaesthesia was induced with ketamine $1.5 \mathrm{mg} \cdot \mathrm{kg}^{-1}$. After $40-60 \mathrm{sec}$, when sleep was induced, vecuronium $100 \mu \mathrm{g} \cdot \mathrm{kg}^{-1}$ was injected intravenously. The times between the completion of the injection of vecuronium and the development of $\mathrm{T}_{1} /$ control ratio of $50 \%$ and $10 \%$ were recorded, and were considered as the onset times to $50 \%$ and $90 \%$ neuromuscular block respectively. The onset times in the Caesarean group were compared with that achieved in the control nonpregnant groups of patients. Also, the time of recovery to $\mathrm{T}_{1}$ /control ratio of $25 \%$ was compared in the two groups.

\section{Conditions of tracheal intubation}

Laryngoscopy was performed in all patients at $50 \%$ neuromuscular block, and conditions for tracheal intubation were scored according to Table I as excellent, good, fair, or poor. Tracheal intubation was performed when the score was excellent or good, and was not done when the score was fair or poor. In the latter conditions, intubation was performed at $90 \%$ neuromuscular block.

Administration of oxygen by face mask, without assisting ventilation, was continued throughout the period of induction until the trachea was intubated. Following tracheal intubation, the lungs of patients undergoing
TABLE I Intubation scores

\begin{tabular}{|c|c|c|c|}
\hline Score & Jaw & Vocal cords & $\begin{array}{l}\text { Diaphragmatic } \\
\text { movement }\end{array}$ \\
\hline Excellent & Relaxed & $\begin{array}{l}\text { Abducted and } \\
\text { immobile }\end{array}$ & Absent \\
\hline Good & Relaxed & $\begin{array}{l}\text { Abducted and } \\
\text { immobile }\end{array}$ & Slight "bucking" \\
\hline Fair & Relaxed & Moving & "Bucking" \\
\hline Poor & Not relaxed & Closed & "Bucking" \\
\hline
\end{tabular}

TABLE II Onset time to $50 \%$ and $90 \%$ neuromuscular block (NMB), and time to $25 \%$ recovery

\begin{tabular}{lcc}
\hline & Caesarean group & Control group \\
\hline Onset time (sec) & & \\
$50 \%$ NMB & $80 \pm 30$ & $144 \pm 43$ \\
$90 \%$ NMB & $125 \pm 66$ & $288 \pm 163$ \\
Recovery to 25\%(min) & $46 \pm 10$ & $28 \pm 10$ \\
\hline
\end{tabular}

Caesarean section were ventilated with $100 \%$ oxygen until delivery of the fetus. After delivery, anaesthesia was maintained with nitrous oxide:oxygen mixture $(2: 1)$, supplemented with fentanyl $3 \mu \mathrm{g} \cdot \mathrm{kg}^{-1}$. In the nonpregnant control patients, nitrous oxide:oxygen administration started after tracheal intubation. At the end of surgery, which lasted 30-60 min, neuromuscular blockade was reversed in both groups with a mixture of atropine 0.02 $\mathrm{mg} \cdot \mathrm{kg}^{-1}$ and neostigmine $0.05 \mathrm{mg} \cdot \mathrm{kg}^{-1}$.

All data other than intubation scores are reported as mean \pm standard deviation (SD), and Student's t test was used to compare data. Chi-square was used to compare the intubation scores. $P<0.05$ was considered significant.

\section{Results}

\section{Onset of neuromuscular block}

The mean onset times to $50 \%$ and $90 \%$ neuromuscular block are shown in Table II. In patients undergoing Caesarean section, the onset time was shorter than that observed in the control nonpregnant women $(P<0.05)$. Recovery of $\mathrm{T}_{1}$ /control ratio of $25 \%$ was longer in the pregnant patients $(46 \pm 10 \mathrm{~min})$ than in the nonpregnant patients $(28 \pm 10)(P<0.05)$.

\section{Intubation scores}

The conditions for tracheal intubation at 50\% neuromuscular block in both groups were excellent or good in $90 \%$ of the patients, and in only one patient in each group was the trachea not intubated (Table III). The tracheas which were not intubated at $50 \%$ neuromuscular block could be easily intubated at $90 \%$ block. In all patients, oxygen 
TABLE III Intubation scores as assessed during laryngoscopy and $50 \%$ neuromuscular block

\begin{tabular}{lll}
\hline Intubation score & Caesarean group & Control group \\
\hline Excellent & 7 & 9 \\
Good & 2 & 0 \\
Fair & 1 & 1 \\
Poor & 0 & 0 \\
\hline
\end{tabular}

saturation as monitored by pulse oximetry ranged between $98 \%$ and $100 \%$ during the induction-intubation interval.

\section{Discussion}

The present report shows that the onset of vecuronium neuromuscular block is more rapid in patients undergoing Caesarean section than in nonpregnant women. The rapid onset of block in the pregnant patient may be attributed to the increased cardiac output. During pregnancy, the cardiac output increases by about $35 \%$ by the eighth week of gestation, and may remain elevated to term, ${ }^{3}$ unless decreased by the supine hypotensive syndrome. ${ }^{4}$ Also, the blood flow to most organs including the limbs increases during pregnancy by decreasing the peripheral resistance to accommodate the increased cardiac output. ${ }^{5}$ Blood flow appears to be a determinant factor which speeds the onset of neuromuscular block. ${ }^{6,7}$ During pregnancy, blood flow is increased, while blood protein concentrations are decreased $^{8}$ with a possible decrease of protein binding of vecuronium, thereby increasing the amount of free drug delivered to the site of action.

The rapid onset of neuromuscular block in the pregnant women may also be attributed to a relative overdose when vecuronium is administered according to body weight. Vecuronium, in common with other muscle relaxants, does not cross the placental barrier to reach the fetus in clinically important concentrations. ${ }^{9}$ Also, vecuronium may not readily redistribute to the fat which has accumulated and the water which is retained during pregnancy and which partially contribute to the increased body weight of the parturient. The mean weight of our patients undergoing Caesarean section was higher than the mean body weight of the control nonpregnant group. Similar to the obese patient, ${ }^{10}$ administration of vecuronium according to body weight represents a relative overdose. Our present report showed that recovery of $\mathrm{T}_{1}$ /control ratio to $25 \%$ was longer in the pregnant than in the nonpregnant control group of patients. Previous investigations have shown that patients undergoing Caesarean section require on a weight basis, smaller doses of vecuronium than normal, to maintain muscle relaxation ${ }^{11}$ and the increased response to vecuronium has been observed also in postpartum patients within one to four days after delivery. ${ }^{12,13}$

Although the onset of $50 \%$ and $90 \%$ vecuronium neuromuscular block was more rapid in the pregnant patients, tracheal intubation could be readily achieved in both groups at $50 \%$ vecuronium block when a ketaminevecuronium sequence was used for induction of anaesthesia. Central well-perfused muscles of the upper airway may be totally blocked when the adductor pollicis is only $50 \%$ blocked. ${ }^{14}$ Also, ketamine induction may obtund the airway reflexes. Previous reports have also shown that ketamine induction better attenuates the haemodynamic response to laryngoscopy and intubation than thiopentone ${ }^{15}$ and can decrease the incidence of bronchospasm. $^{16,17}$

Because of the rapid onset of $50 \%$ block in the parturient, ketamine-vecuronium may be considered as an alternative technique for rapid-sequence intubation in patients undergoing Caesarean section, without the need for "priming" 18,19 or "high-dose" techniques. ${ }^{20}$ The "priming" technique has some risks which include the distressing sensation of dyspnoea, respiratory impairment, and possible aspiration of gastric contents. ${ }^{21}$ The "highdose" technique, although it decreases the onset time, prolongs the duration of neuromuscular block which may exceed the operative time. ${ }^{20}$ Succinylcholine, when not contraindicated, remains the muscle relaxant of choice in situations - including Caesarean section - where a rapidsequence induction of anaesthesia is indicated. ${ }^{22,23}$

In conclusion, the present report shows that the mean onset time to $50 \%$ and $90 \%$ neuromuscular block following ketamine-vecuronium sequence is shorter in patients undergoing Caesarean section than in nonpregnant women of the same age, and that tracheal intubation can be easily performed at $50 \%$ neuromuscular blockade. The time of recovery to $T_{1}$ /control ratio of $25 \%$ is longer in the Caesarean group. The results suggest that administration of vecuronium according to body weight results in a more rapid onset of neuromuscular block and delayed recovery in the pregnant women undergoing Caesarean section than in the nonpregnant control patients.

\section{References}

1 Hawkins JL, Johnson TD, Kubicek MA, Skjonsby BS, Morrow DH, Joyce III TH. Vecuronium for rapidsequence intubation for cesarean section. Anesth Analg 1990; 71: 185-90.

2 Baraka A, Louis F, Delleh $R$. Maternal awareness and neonatal outcome after ketamine induction of anaesthesia for Caesarean section. Can J Anaesth 1990; 37: 641-4.

3 Lees MM, Taylor SH, Scott DB, Kerr MG. A study of cardiac output at rest throughout pregnancy. J Obst Gyn Br Commonwealth 1967; 74: 319-28.

4 Howard BK, Goodson SH, Mengert WF. Supine hypotensive syndrome in late pregnancy. Obs Gyn 1953; 1: 371-7. 
5 Ginsburg J, Duncan S. Peripheral blood flow in normal pregnancy. Cardiovascular Research 1967; 1: 132-7.

6 Harrison GA, Junius $F$. The effect of circulation time on the neuromuscular action of suxamethonium. Anaesth Intensive Care 1972; 1: 33-40.

7 Goat VA, Yeung ML, Bladeney $C$ et al. The effect of blood flow upon the activity of gallamine triethiodide. $\mathrm{Br}$ J Anaesth 1976; 48: 69-73.

8 Ganrot $P O$. Variation of the concentrations of some plasma proteins in normal adults, in pregnant women and in newborns. Scand J Clin Lab Invest 1972; 29: 83-8.

9 Demetriou M, Depoix JP, Diakite B, Fromentin M, Duvaldestin $P$. Placental transfer of Org NC45 in women undergoing caesarean section. Br J Anaesth 1982; 54: 643-5.

10 Weinstein JA, Matteo RS, Ornstein E, Schwartz AE, Goldstoff $M$, Thal $G$. Pharmacodynamics of vecuronium and atracurium in the obese surgical patient. Anesth Analg 1988; 67: 1149-53.

11 Baraka A, Noueihid R, Sinno H, Wakid N, Agoston S. Succinylcholine vecuronium (ORG NC45) sequence for cesarean section. Anesth Analg 1983; 62: 909-13.

12 Camp CE, Tessem J, Adenwala J, Joyce III TH. Vecuronium and prolonged neuromuscular blockade in postpartum patients. Anesthesiology 1987; 67: 1006-8.

13 Khuenl-Brady KS, Koller J, Mair P, Puhringer F, Mitterschiffthaler $G$. Comparison of vecuronium and atracurium in postpartum and nonpregnant patients. Anesth Analg 1991; 72: 110-3.

14 Chauvin $M$, Lebrault $C$, Duvaldestin $P$. The neuromuscular blocking effect of vecuronium on the human diaphragm. Anesth Analg 1987; 66: 117-22.

15 Schultetus RR, Paulus DA, Spohr GL. Haemodynamic effects of ketamine and thiopentone during anaesthetic induction for Caesarean section. Can Anaesth Soc J 1985; 35: 592-6.

16 L'Hommedieu CS, Arens JJ. The use of ketamine for the emergency intubation of patients with status asthmaticus. Ann Emerg Med 1987; 16: 568-71.

17 Hirshman CA, Downes H, Farbood A, Bergman $N A$. Ketamine block of bronchospasm in experimental canine asthma. Br J Anaesth 1979; 51: 713-8.

18 Schwarz S, llias W, Lackner F, Mayrhofer O, Foldes FF. Rapid tracheal intubation with vecuronium: the priming principle. Anesthesiology 1985; 62: 388-91.

19 Toboada JA, Rupp SM, Miller RD. Refining the priming principle for vecuronium during rapid-sequence induction of anesthesia. Anesthesiology 1986; 64: 243-74.

20 Ginsberg B, Glass PS, Quill T, Shafron D, Ossey $K D$. Onset and duration of neuromuscular blockade following high-dose vecuronium-administration. Anesthesiology 1989; 71: 201-5.
21 Sosis $M$. A caution on vecuronium priming. Anesthesiololgy 1985: 63: 460.

22 Cicala $R$, Westbrook $L$. An alternative method of paralysis for rapid-sequence induction. Anesthesiology 1988; 69: 983-6.

23 Baraka A. Rapid onset of suxamethonium block. Br J Anaesth 1991; 66: 733. 